\title{
火災区画内の対流熱伝達に及ぼす換気の影響 \\ VENTILATION EFFECTS ON CONVECTIVE HEAT TRANSFER IN COMPARTMENT FIRES
}

\author{
山田茂*, 田中哮義**, 吉野＼cjkstart博*** \\ Shigeru YAMADA, Takeyoshi TANAKA and Hiroshi YOSHINO
}

\begin{abstract}
The objective of this study is to develop a simple and practical model for predicting overall convective heat transfer coefficient in compartment fires. Experiments using a small scale $(500 \mathrm{~mm}$ cube) and a medium scale $(1,500 \mathrm{~mm}$ cube) compartments were conducted to investigate the influence of ventilation on convective heat transfer coefficient. As a result, the following findings have been obtained. (1) Convective heat transfer coefficients in case that there are both of the flow induced by heat release of origin and the one induced by ventilation are always lager than in case that there is no ventilation. (2) The convective heat transfer coefficient can be divided into two components, i.e. one due to the flow induced by heat release of origin and the other due to the flow induced by ventilation. (3) The part of the convective heat transfer coefficient due to ventilation can be expressed as a function of the dimensionless opening mass flow rate.
\end{abstract}

Keywords : compartment fire, convective heat transfer, dimensionless heat release rate, dimensionless heat transfer coefficient

区画火災、対流熱伝達、無次元発熱速度、無次元熱伝達率

\section{1.はじめに}

本研究は対流熱伝達率の実用的な予測式を開発することによって 区画火災性状の工学的予測精度の向上に寄与することを目的として いる。ここで火災性状予測手法としてはゾーンモテルを念頭におい ているのて、対流熱伝達の予測式は、局所の情報を必要とするもの ではなく、層の平均的物理量をもとに評価できる簡易なものとする ことを目標とする。

一般に対流熱伝達速度を評価するには、気体と伝熱面の温度、及 び対流熱伝達率の評価が必要でる。火炎区画の平均的な性状の予 測を対象亡する場合、気体と伝熱面の温度については、それぞれ区 画内の気体の平均温度および周壁表面の平均温度を採るのが最も自 然で、実用的てあろう。すると、これに伴って対流熱伝達率も区画 内の平均的な值を評価することが必要となる。

対流熱伝達率は一般に伝熱面が曝される気流の性状に影響される。 火災区画内の気流性状は、天井下と垂直壁面近傍ては異なり、また 火源からの距離によっても差異がある。従って、対流熱伝達率は部 位毎に異なり、火災区画内の平均対流熱伝達率は、これらが総合さ れた值である。

既報1.2)では、火災のごく初期に見られるような、開口を通して の換気が室内への気流場に及ぼす影響が軽微な条件下を想定して、
立方形状の火災区画内の対流熱伝達を調べた。そして、このような 条件ては、火災区画内の気流の速度や方向は、火災区画内の位置毎 に異なったとしても、全て火源の発熱か駆動する流れであり、従っ て流速も熱伝達率も火源の発熱速度と火災区画のスケールの関数と なっているでろうとの考えから、寸法の異なる3つの相似の区画 における熱伝達性状を、無次元発熱速度と無次元平均熱伝達率で整 理した。この結果、これらのパラメターが寸法の異なる相似の区画 における熱伝達性状を説明するために有効であることが分かった。

一方、火災が更に進展して、火災区画の開口を介する換気が盛ん になると、流入する空気が区画内の気流性状に影響を及ぼすことが 考えられ、これが対流熱伝達率に関係する可能性が出てくる。そこ で本研究では、2つの寸法の異なる相似の火災区画模型を用いた実 験により、開口を介する換気がある時期における対流熱伝達率を調 ベることとした。

\section{2. 研究の方法}

\section{1 熱伝達速度Qc 及び熟伝達率 h}

室内周壁への熱伝達速度 $\mathrm{Q}$ c、火源の発熱速度 $\mathrm{Q}$ 、換気に上る失 熱速度Qdの間には

$Q c=Q-Q d$
*フジタエンジニアリング本部 博士 (工学)

** 京都大学防災研究所 教授・工博

*** 東北大学大学院工学研究科都市・建築学専攻 教授・工博
Engineering Dept., Fujita Corporation, Dr. Eng.

Prof., Disaster Prevention Research Institute, Kyoto Univ., Dr. Eng.

Prof., Dept. of Architecture and Building Science, Graduate School of Engineering, Tohoku Univ., Dr. Eng. 
の関係がある。従って、換気による失熱速度 $\mathrm{Qd}$ 、区画内の火源の 発熱速度 $Q$ を測定し、さらに層と表面の温度差 $\Delta T$ 及び伝熱面積 Aが評価できれば、対流熱伝達率 hは

$$
h=Q c /(\Delta T \cdot A)
$$

で算出できることになる。

\section{2 換気による失熱速度 Qd}

開口から流出する空気の質量速度md、流入する質量速度 $\mathrm{m}$ i 及び 火源からの可燃ガスの発生速度 $\mathrm{mp}$ の間には

$m d=m p+m i$

の関係があるが、md及びmiに比較し、mpは通常無視できるので、 $m d \stackrel{m i}{\sim}$

とみなせる。そこで、流入空気の温度を $\mathrm{T}$ i、流出空気の温度を $\mathrm{T} d$ 亡する亡、換気による失熱速度Qdは下式で求められる。

$$
\begin{aligned}
Q_{d} & =C_{p} T d m d-C_{p} T_{i} m_{i} \\
& =C_{p}\left(T_{d}-T i\right) m d
\end{aligned}
$$

なお、開口噴流の質量流速md は、既報 ${ }^{3)}$ で報告しているガス分 析に基づく手法により測定する。

\section{3. 実験概要}

規模の異なる 2 種類の区画模型を用いて、同じ手法で実験を行い、 さらに発熱速度及び開口形状を変えることにより、これらの要素之 熱伝達率との関係を調べた。

ここで、実験における測定は、定常状態とみなせる時期を前提と している。

火源の発熱速度の測定手法、並びに以下に示す区画模型 2 に関し ては既報るに詳述している。

\section{1 区画模型及び捕集フード}

燃焼箱は愿さ $12 \mathrm{~mm}$ のパーライト板に厚さ $3 \mathrm{~mm}$ のステンレス板 を内貼りした内法 $500 \mathrm{~mm}$ 立方の区画模型（区画模型1とする）及 び内法 $1500 \mathrm{~mm}$ 立方の区画模型（区画模型 2 とする）て、これら は相似形である。区画模型 2 の平面及び断面を図 1 に示扵。

図 2 に示すように、内貼りのステンレス板は各面 9 分割し、板の 裹面中央を切り欠き熱電対を埋め込んでいるがこれにより内表面 温度が十分な精度で測定できる には、形状の異なる開口を有するパネルを取付けることができ、こ れにより開口条件を变化させることができる。開ロパネルに設けた 開口寸法を表 1 中に示す。

また、開口の外部上方には開口から流出するガスを捕集するため、 図 1 に示す大フードを設置した。大フードにはダクトを接続し、そ

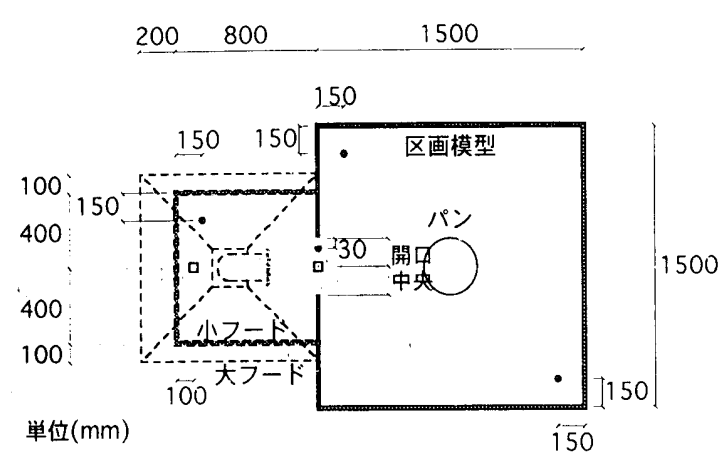

(1) 平面図

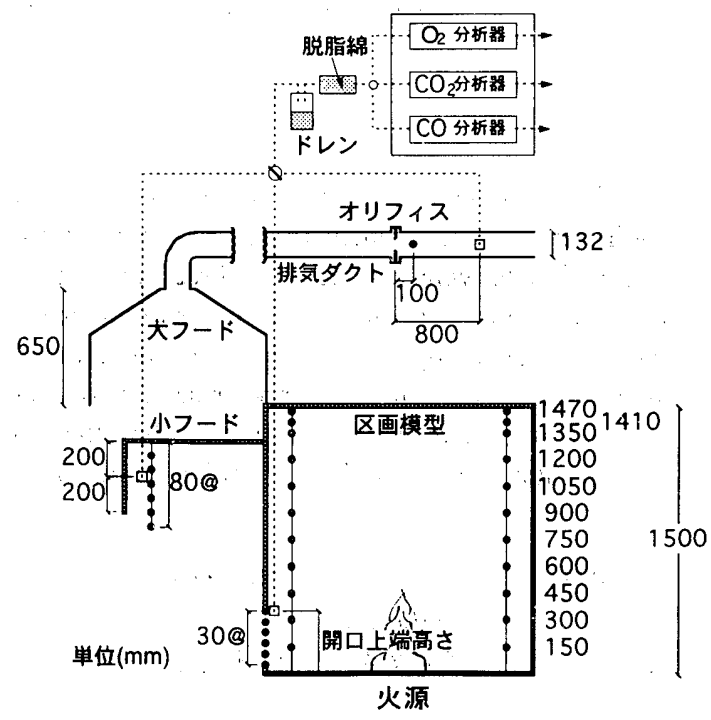

(2) 断面図

ガス採取位置

温度測定位置

図 1 区画模型 2 とガス捕集装置及び測定位置

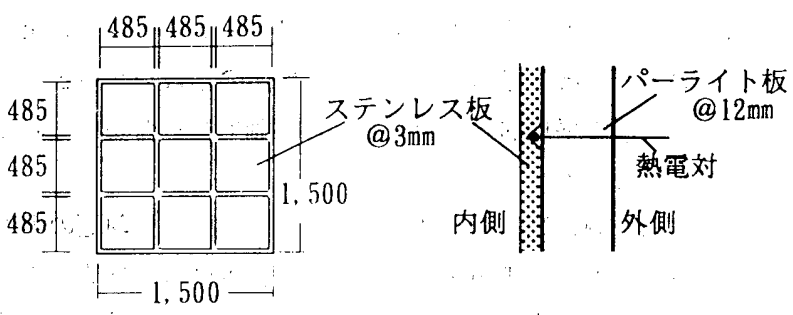

(1) ステンレス板内貼り状況

図2.ステンレス板及び熱電対設置状況

表 1 開口寸法と火源の大きさ（○：実験を実施した条件）

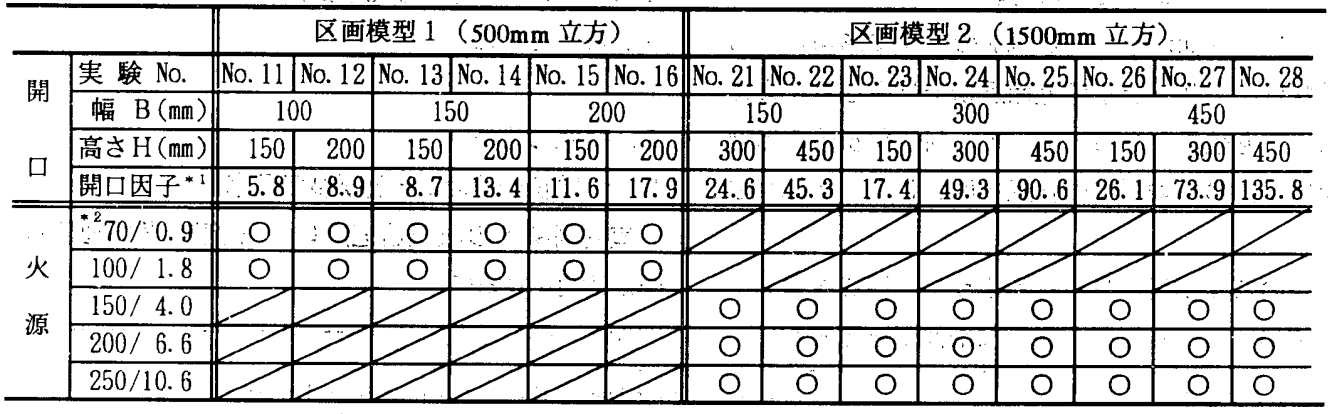

*1 $\mathrm{B} \mathrm{H}^{3 / 2}\left(\times 10^{-3} \mathrm{~m}^{5 / 2}\right)$

*2 火源直径 $(\mathrm{mm}) /$ 自由空間中の発熱速度 $(\mathrm{k} N)$ 
の端部には捕集ガスを吸引するための排気ファンを設置した。ダク ト内には流量測定のためのオリフィスを取り付けている。なお、大 フンドの下に高さを可変とした小フードを設置しているか、これは 別に並行して行っている開口噴流ブルームの流量測定の際に巻き込 み高さを明確にするためて、本研究の目的では特に必要なく、また 測定への影響もない。

\section{2 火源及び発熱速度}

底面中央部にアルコールパンを設置し、径の異なるパンを用いる ことにより発熱速度を変化させた。燃料はメタノールを使用した。 パンの径は、燃焼速度と開口因子の大きさを考慮しながら、区画内 で不完全燃焼を生じないと考えられる範囲で設定した。表 1 中に火 源の大きさを示す。発熱速度は、区画内の伝熱性状によってメ夕ノ 一ルの蒸発速度が变化するため、各実験毎にガス分析に基づき酸素 消費法により算定するが、参考として自由空間中での測定結果 ${ }^{2)}$ 示している。

\section{3 測定項目及び測定方法}

測定項目を以下に示す。なお、区画模型 2 の測定位置を図 1 中に 示しているが、区画模型 1 の箱内の温度測定位置は区画模型 2 の測 定位置と相似の $1 / 3$ の寸法の位置である。

- 区画内空気温度 : 垂直方向 11 点 $\times$ 平面上の 2 ヶ所

・開口部温度：開口端から水平方向に $30 \mathrm{~mm}$ 、開口上端から 下端まで区画模型 1 は $15 \mathrm{~mm} 、$ 区画模型 2 は $30 \mathrm{~mm}$ 間隔

·周辺空気温度

・ガス濃度 $\mathrm{O}_{2} 、 \mathrm{CO}_{2} 、 \mathrm{CO}$ (区画内、小フード内、排気ダクト内）

·排気ダクト内オリフィス板前後差圧、空気温度

・ 区画内壁表面温度 : 開口部のある面及び底面 8 点、他は 9 点

3. 4 実験の手順

火源に着火後20分程度で各測定值がほぼ定となり、定常と考え られる状態になるのが確認された。デー夕の収録はこの定常状態亡 みなせる時期に 30 秒間、 1 秒間隔に行った。

計測を行った後、火源を鎮火させた。そして、開ロパネル及びア ルコールパンを変え、次の実験を行った。

\section{5 ガス分析による開口噴流質量流速及び発熱速度の算定法}

詳細は既報 ${ }^{32}$ に示しているのて、ここでは要点のみ記述する。

1 ）開口噴流の質量流速の算定

各部の濃度 $\mathrm{Y}$ 及び排気ダクト内の質量流速 $\mathrm{m}_{\mathrm{E}}$ から開口噴流の質 量流速mdが下式で求められる。

$$
m d=\frac{Y_{L}^{a}-Y_{L}^{\delta}}{Y_{L}^{a}-Y_{L}^{D}} m_{B}
$$

\section{2 ）区画内火源の発熱速度の算定}

発熱速度はメ夕ノールの燃焼による酸素の質量消費速度に、メ夕 ノールの単位酸素消費量当たり発熱速度 $13.220 \mathrm{~kJ} / \mathrm{kg}\left(\mathrm{O}_{2}\right)$ を乗ずれ ば得られることから、酸素濃度から算出する速度Q(02)は、䨌囲気 空気の酸素質量分率 $\mathrm{Y}_{02}^{\mathrm{a}}$ 、排気ダクト内の酸素質量分率 $\mathrm{Y}_{02}^{\mathrm{E}}$ 、排気 ダクト内の質量流速 $\mathrm{m}_{\mathrm{E}}$ より下式で与えられる。

$Q_{\left(O_{2}\right)}=13,220\left(Y_{O 2}^{a}-Y_{O 2}^{B}\right) m_{B}$

また、 $\mathrm{CO}_{2}$ 濃度の変化を利用して、下式でも算出できる。

$Q_{\left(\mathrm{CO}_{2}\right)}=13,220 \frac{3}{2}\left(\frac{32}{44}\left(Y_{\mathrm{CO}_{2}}^{\mathrm{s}}-Y_{\mathrm{CO}_{2}}^{a}\right)\right) m_{E}$
なお、上式の質量分率Y o2、Y $\mathrm{CO}_{2}$ を、ガス分析により測定され る体積分率を基に算出する方法については既報ぶを参照のこと。

\section{4. 実験結果}

\section{1 区画内の火源の発熱速度 O}

図 3 に、式(5)により O2 濃度から算出した発熱速度及び式(6)に より $\mathrm{CO}_{2}$ 濃度から算出した発熱速度亡、これらの平均亡を比較し た結果を示す。2つの区画ともやや差がある場合があるが、絶対量 が微少であるこを考慮すると、比較的精度よく測定されている亡 考えられる。 $\mathrm{O}_{2}$ 濃度と $\mathrm{CO}_{2}$ 濃度を用いた算出値との間に若干の差 があることを考虑し、本研究では発熱速度の值としては、 $\mathrm{O}_{2}$ 濃度 からの算出値亡 $\mathrm{CO}_{2}$ 濃度からの算出值との平均を用いること亡す る。

図 4 には、発熱速度と開口因子 $\mathrm{A} \mathrm{H}^{1 / 2}$ 及び自由空間で燃焼させ て測定した発熱速度との比較を示す。区画内での発熱速度と自由空 間中の発熱速度を比較すると、概ね一致しているが、最大 $25 \%$ 程度 の差も見られる。この原因としては以下のようなことが考えられる。

まず、本実験中の発熱速度の方が大きくなっているのは、区画内 高温ガスからの対流及び輻射熱伝達、周壁からの輻射熱伝達により メタノールが加熱されて、自由空間中での燃焼に此較し蒸発速度が 大きくなっていることが原因と考えられる。また、区画模型 2 では、 本実験中の発熱速度の方が小さくなっている場合もあるが、これは 開口が小さいときで、この場合換気量が少ないために区画内部での 発熱が抑えられ、その結果メ夕ノールの蒸発速度が低下しているこ とが原因と考えられる。

\section{2 換気による失熱速度 $\mathrm{Od}$}

換気による失熱速度を算出する式(3)の開口噴流の温度 Tdには、 開口部における中性帯高さから開口上端高さまでの平均值を用いる こととする。ここで図 5 に、区画内及び開口部の垂直温度分布の一

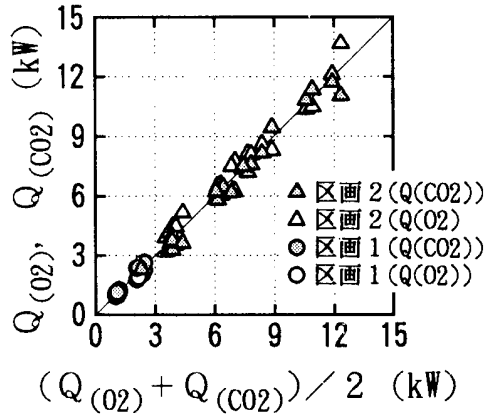

図 $3 \mathrm{O}_{2}$ 濃度及び $\mathrm{CO}_{2}$ 濃度からの発熱速度算出値

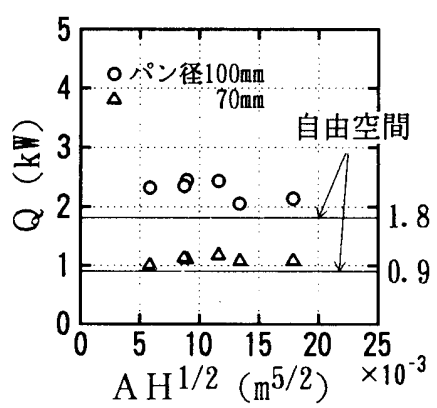

(1)区画模型 1

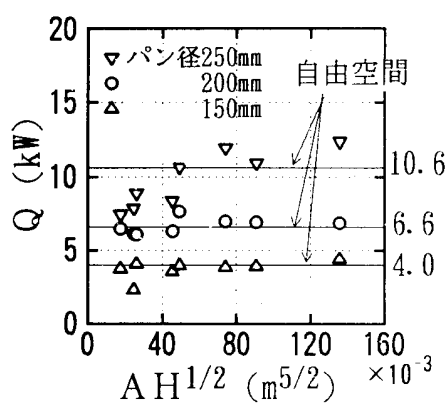

(2)区画模型 2 


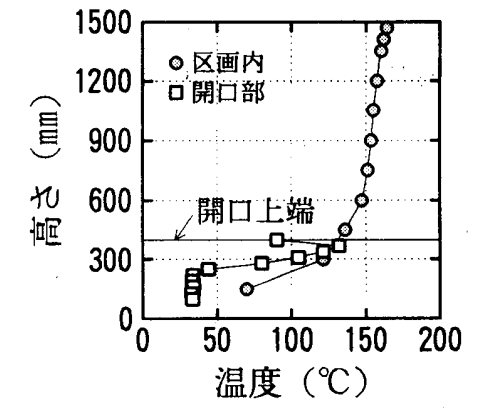

図 5 区画内及び開口部の垂直温度分布

\section{例を示す。}

さて、中性帯高さについては、空気の流入と流出の境界の高さが 中性帯の高さであることから、以下に示すように、開口部の温度計 測值から中性帯の高さを推定した。

まず開口部の温度測定值の最高值を $\mathrm{T} \max 、$ 最低值を $\mathrm{T}$ min と表し、 参照温度 $\mathrm{T}_{\mathrm{n}}$ を

$T_{n}=N\left(T_{\max }-T_{\min }\right)+T_{\min }$

とした。そして測定値を直線補間して、 $\mathrm{T}$ 在す高さを算出し、 これを中性帯高さとした。ここで、N=0.1としだ”。

図6に、換気による失熱速度を開口形状を表すパラメー夕 $\mathrm{A} \mathrm{H}^{1 / 2}$ に対してプロットした結果を、また図 7 に失熱速度の発熱速度に占 める割合の、開口因子に対する依存関係を示す。

図 6 から区画 1 の一部を除き、A $\mathrm{A}^{1 / 2}$ が大きくなるに従って換 気による失熱速度は大きくなり、パン径が大きくなると失熱速度も 大きくなるのがわかる。しかし、図 7 に示すように、失熱速度の発 熱速度に対する割合を見る亡、発熱速度による差はあまり見られな
くなる。

\section{3 伝熱面積 $A$ 、及び区画内空気と表面の温度差 $\Delta T$}

式(2)により区画全体の対流熱伝達率を算出するには、伝熱面積 $\mathrm{A}$ 、及び区画内空気と表面の温度差 $\Delta T$ が得られなければならない。 そのためにまず、区画内の温度性状を調べた。

図 8 及び図 9 に、区画内空気及び周壁表面の垂直温度分布を示す。 空気温度は同じ高さの 2 点の平均でる。表面温度は、各面共 9 分 割して内貼りしたステンレス板の中央部で測定している ${ }^{122}$ が、天 井はこの 9 点の平均、壁の上段は 4 面の平均、中段及び下段は開口 部のある面を除く 3 面の平均、床は火源を設置した中央を除く 8 点 の平均としている。

図 8を見ると、開口の形状が異なると温度に差が生じるが、いず れの場合も開口上端より上部ではほぼ均一に高温となり、一方下部 では低温を示し、2 層を形成していることがわかる。

そして、それらの層の境界面の高さを推定する手法としては、 Cooper のN\%法" に準じた手法として、区画内の最高温度と最低 温度から推定するか、あるいは、中性帯の高さを算出し、層の境界 面高さもこれにほぼ一致すると考えて推定することが考えられる。

そこで、これらの手法で模型区画 2 について計算した結果、前者 の手法て求めた境界面の高さは実験条件によって異なるが、その值 は $122 \sim 158 \mathrm{~mm}$ 、後者の手法で求めた中性帯高さは $60 \sim 260 \mathrm{~mm} て$ あった。区画の高さが $1500 \mathrm{~mm}$ でるのて、上方 $90 \%$ 程度が上部 高温層て、下部層はわずかであると言える。そこで、本研究では下 部層は無視し、区画全体を 1 層（高温首）とみなすこととした。

その理由は、全体の 90\%程度が高温層となっているので、残り 10\%程度の下部層は無視できると考えたことと、2 層を仮定した場

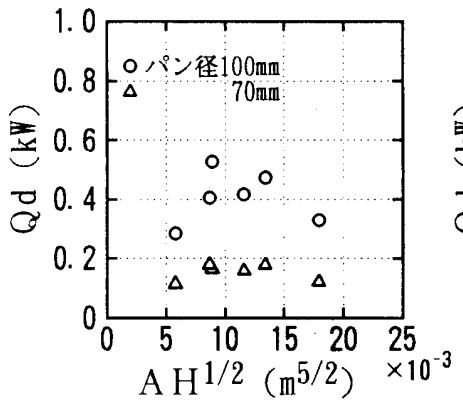

(1) 区画模型 1

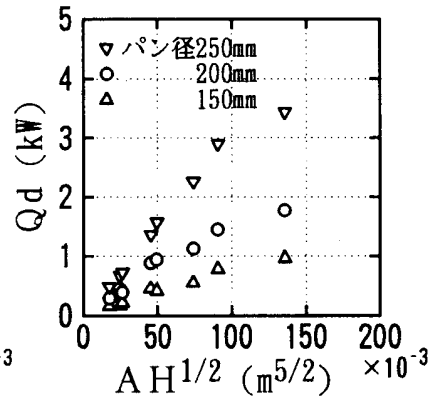

(2)区画模型 2

図 6 開口からの失熱速度

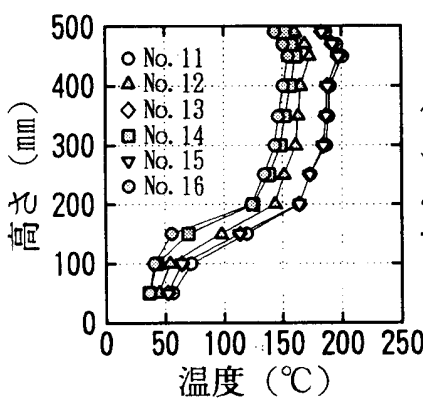

（1）区画模型 1 (パン径 70mm）（2）区画模型 2 (パン径 $200 \mathrm{~mm}$ ) 図 8 区画内空気の垂直温度分布

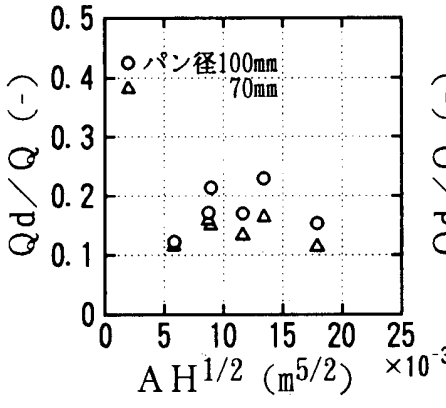

(1) 区画模型 1

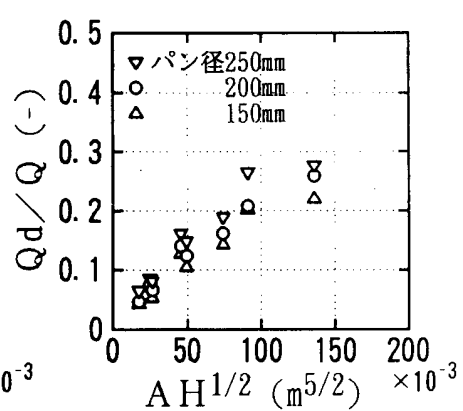

(2)区画模型 2

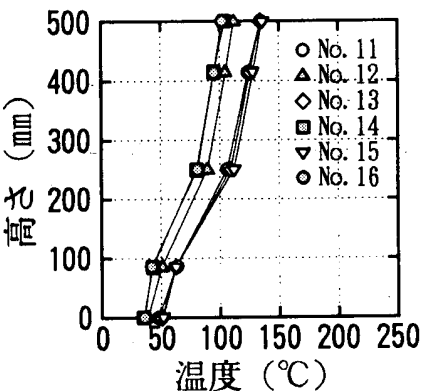

（1）区画模型 1 (パン径 70mm）（2）区画模型 2 (パン径 200mm)

図 9 周壁表面温度の垂直温度分布

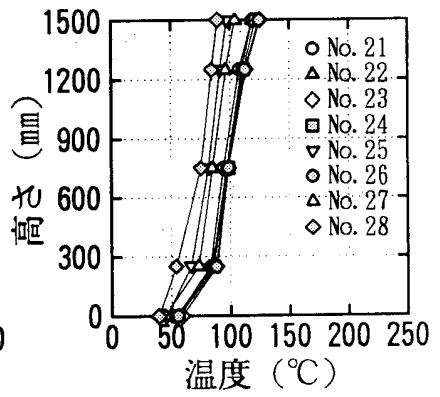


合、上部首からの対流熱伝達量亡下部層からの対流熱伝達量の割合 が不明なこと、前報1.2て で災初期における熱伝達率の推定におい ても 1 層とみなしており、同じ扱いをした方が比較の際に便利であ ると考えたためである。

模型区画 1 でも、模型区画 2 の場合と同じように上部高温首と下 部低温層の 2 層を形成していることが窺える。模型区画 2 の場合と 比較して、区画の高さに対する開口の高さの割合が大きいのて、層 の境界面はやや高い。しかし、上記したように 2 層に分割して考え ることは本研究手法では不都合なため、ここでも区画内は 1 層と考 えることとした。

従って、伝熱面積は床を除〈周壁全体とする。これも既報 $\left.{ }^{12}{ }^{2}\right)$ と 同じ扱いである。図 9 から床の温度上昇は小さいことがわかるので、 床を除くことは妥当と考える。

区画内空気と表面の温度差を、開口因子を横軸によって図10に示 す。2つの区画共に、パン径が大きいほど温度差は大きく、開口因 子が大きいほよ゙温度差は小さくなっている。

\section{4 輻射熱伝達}

既報"に示したものと同じ方法で、輻射熱伝達速度を推定した。

そして、上記した区画全体の熱伝達速度の大きさと比較した結果、 輻射熱伝達速度は全体の 5 〜 25\%程度であった。従って、本研究で は対流熱伝達率という語を用いるが、これには上記の程度の輻射熱 伝達を含む可能性があることになる。なお、これも既報の火災初期 の状態を調べた場合と同様の扱いである。

\section{5 対流熱伝達率よ発熱速度、区画規模及び開口因子との関係} 区画全体の対流熱伝達率 $\mathrm{h}$ の算出結果を、発熱速度 $Q$ 、開口因子 $\mathrm{A} \mathrm{H}^{1 / 2}$ 、開口噴流の質量流量mdに対してプロットしたものを、区 画の規模別にそれぞれ図11及び図12に示す。
発熱速度、開口因子及び開口噴流の質量流量が増大する亡、対流 熱伝達率が增大する傾向が見られる。熱伝達率に対して、発熱速度 の影響が見られるのは、既報 ${ }^{1}$. ${ }^{2)}$ に示した火災初期の性状亡類似し ている。

\section{5. 考察}

\section{1 対流熱伝達率と発熱速度及び区画規模との関係}

既報2〉では、火災初期における対流熱伝達率は、発熱速度上区画 の規模をパラメータとし、無次元発熱速度、無次元熱伝達率を用い るとよく整理できることがわかった。そこで、こでも同じ方法で 整理を試み、火災初期の值と併せてブロットした。図13には無次元 発熱速度と対流熱伝達率、図14には無次元発熱速度上無次元対流熱 伝達率の関係を示す。なお、無次元発熱速度、無次元熱伝達率はそ れぞれ下式で定義する。ここで、Hは区画の高さ（代表寸法）であ る。

$$
Q^{*}=\frac{Q}{C_{p} \rho_{\infty} T_{\infty} g^{1 / 2} H^{5 / 2}}
$$

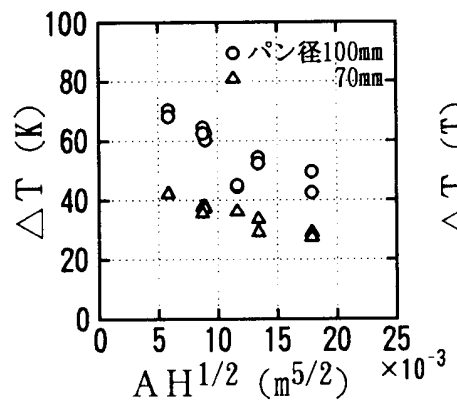

(1)区画模型 1 ( $500 \mathrm{~mm}$ 立方)

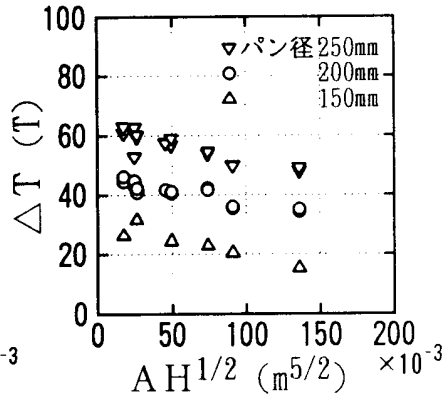

(2)区画模型 2(1,500m立方) 図10 空気と周壁の温度差と開口因子

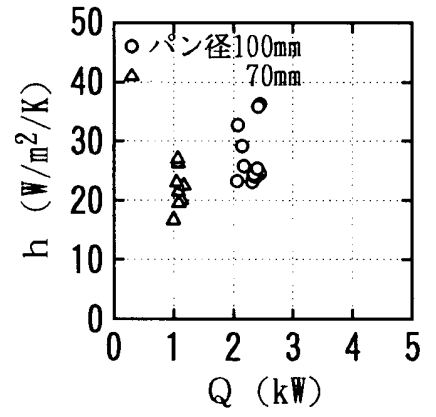

(1)熱伝達率と発熱速度

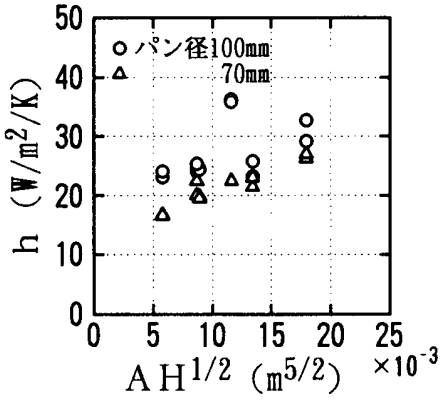

(2)熱伝達率之開口因子

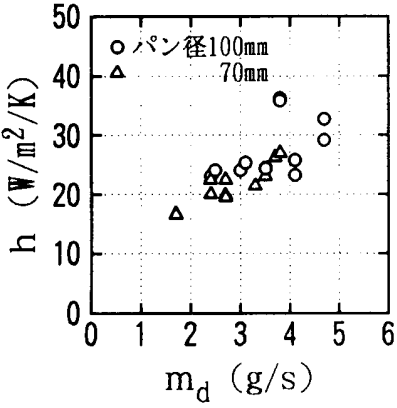

（3）熱伝達率と開口喷流質量流速
図11 熱伝達率と発熱速度、開口因子及び失熱速度（区画模型 1 )

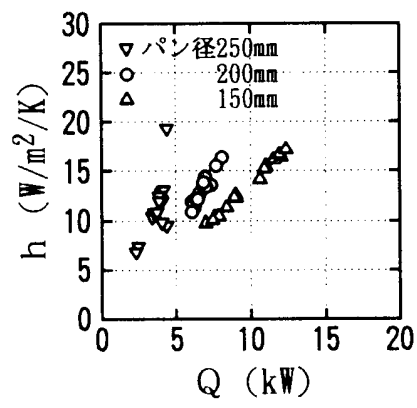

（1）熱伝達率と発熱速度

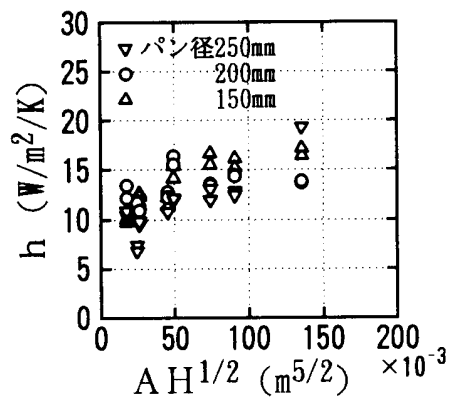

(2)熱伝達率と開口因子

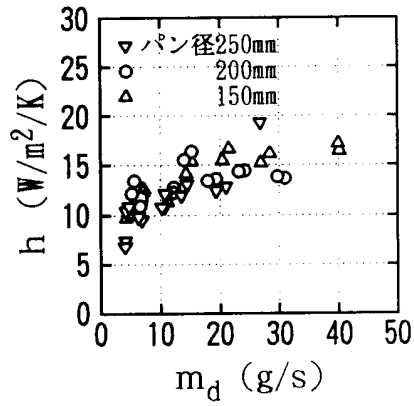

（3）熱伝達率と開口噴流質量流速 図12 熱伝達率と発熱速度、開口因子及び失熱速度（区画模型 2 ） 


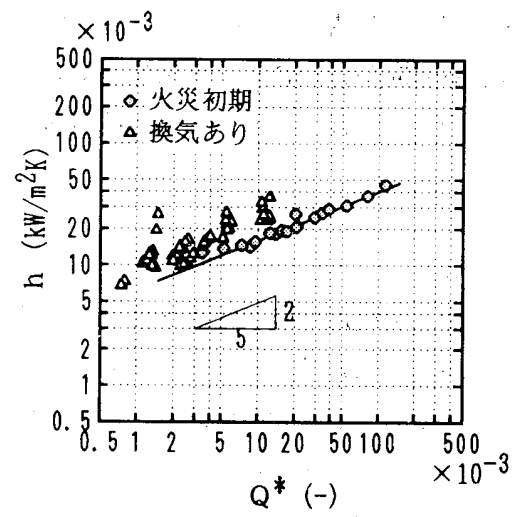

図13 無次元発熱速度と熱伝達率

$$
h^{*}=\frac{h}{C p \rho_{\infty} g^{1 / 2} H^{1 / 2}}
$$

\section{2 熱伝達率の発熱成分と換気成分への分割}

図13から、換気が生じている時期と火炎初期の対流熱伝達率の值 を比較する上、無次元発熱速度の值が同じ場合、前者の值は後者の 值よりも大きくなっていることがわかる。この傾向は対流熱伝達率 を無次元化した図14でも同様でる。これは対流熱伝達率に影響す る区画内の流れが、火災初期には外部からの空気の流入がなく発熱 に起因するものが支配的となっているのに対し、換気が生じている 時期には、発熱に起因する流れに加えて、外部からの流入空気によ る流れが加わることが主な原因と思われる。

そこで対流熱伝達率 h 気による流れに起因する成分 $\mathrm{hd}$ に分割して整理することを試みる。 換気による流れがブルーム性状に影響を与えることにより発熱に起 因する成分にも作用することも考えられるが、ここではこれを無視 し、発熱に起因する成分亡、換気による流れに起因する成分はそれ ぞれ独立である亡仮定する。そして、発熱に起因する成分は既報 ${ }^{2}$ に示したように無次元発熱速度の関数で表すこととする。また、換. 気による流れに起因する成分は、開口噴流の質量流速mdの関数と して整理するが、この值も下式で無次元化することとする。

$$
m d^{*} \equiv \frac{m d}{\rho_{\infty} g^{1 / 2} H^{5 / 2}}
$$

ここで、代表長さHは区画の高さである。

さらに、式(9)による対流熱伝達率の無次元化も行う。

以上から、対流熱伝達率 $\mathrm{h}$ また岋無次元詨流熱伝達率 $\mathrm{h}$ *と、無 次元発熱速度 $\mathrm{Q}$ *及び無次元化した開口噴流の質量流速 $\mathrm{md}^{*}$ "関係 は下式のように表される。

$$
h=f\left(Q^{*}\right)+g\left(m d^{*}\right)
$$

及び

$$
h^{*}=f^{*}\left(Q^{*}\right)+g^{\prime}\left(m d^{*}\right)
$$

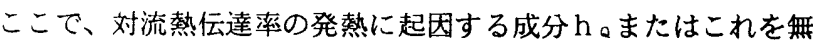
次元化した $\mathrm{h}$ 。 ${ }^{*}$ 之、無次元発熱速度 $\mathrm{Q}$ *の関係は火災初期の性状亡 同じである亡仮定する。つまり、既報”で提案した

$$
h_{0}=0.1\left(Q^{*}\right)^{2 / 5}
$$

及び

$$
\begin{aligned}
& h_{Q^{*}}=2.0 \times 10^{-3} \\
& h_{0^{*}}=0.08\left(Q^{*}\right)^{2 / 3}
\end{aligned}
$$$$
\left(Q^{*} \leqq 4 \times 10^{-3}\right)
$$

で表わされると仮定する。

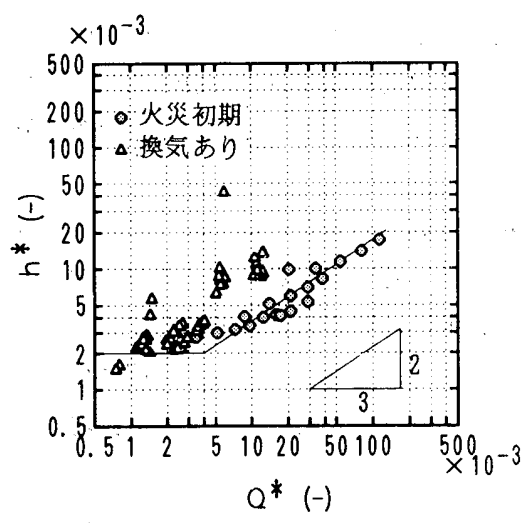

図14 無次元発熱速度と無次元熱伝達率

以上から、対流熱伝達率の換気に起因する流れによる成分は

$h d=h-h$ 。

及び

$h d^{*}=h^{*}-h_{e^{*}}$

で算出されることになる。式(15)に式(13)を、式(16)に式(14)を代 入してhd及びhd*を算出し、md *に対してブロットしたものを図 15及び図16に示す。

やや散らばりはあるが、各デー夕は比較的まとまり、その近似式 はそれぞれ以下のようになる。

$h d=0.27\left(m^{*}\right)^{2 / 3}$ 及び

$h d^{*}=5.1\left(m d^{*}\right)^{4 / 3}$

\section{3 熱伝達率の予測值と実測值}

熱伝達率を、火源の発熱に起因する成分と、換気に上る流れに起 因する成分に分割することを試みた結果、それぞれの予測式が、式 (13)之式(14)、式(17)之式(18)のように得られた。そこで、両方の 成分を加算した熱伝達率の予測式は下式のようになる。

$$
\begin{aligned}
h & =f\left(Q^{*}\right)+g\left(m d^{*}\right) \\
& =0.1\left(Q^{*}\right)^{2 / 5}+0.27\left(m \alpha^{*}\right)^{2 / 3}
\end{aligned}
$$

また、無次元熱伝達率 $\mathrm{h}$ *を用いて

$$
h^{*}=f^{\prime}\left(Q^{*}\right)+g^{\prime}\left(m d^{*}\right)
$$

亡する場合の具体的な回㷌式は

$\mathrm{Q}^{*} \leqq 4 \times 10^{-3}$ の場合

$$
h^{*}=2.0 \times 10^{-3}+5.1\left(m d^{*}\right)^{4 / 3}
$$

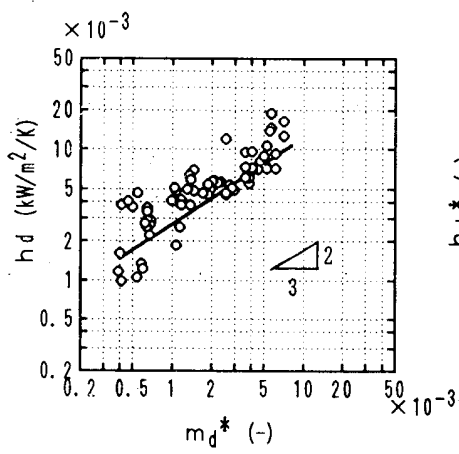

図15 無次元開口噴流 質量流速 と熱伝達率 の換気成分

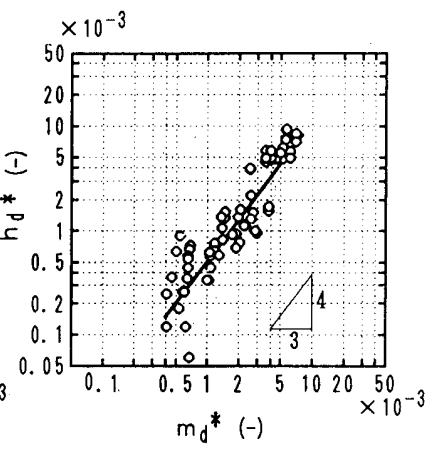

図16 無次元開口噴流質量 流速と無次元熱伝達率 の換気成分 


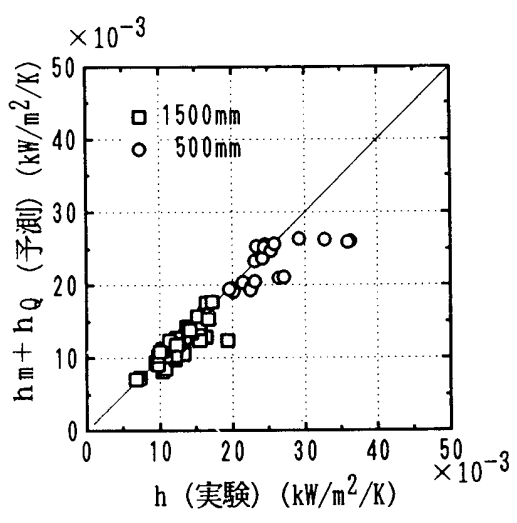

図17 熱伝達率の予測值と実測值

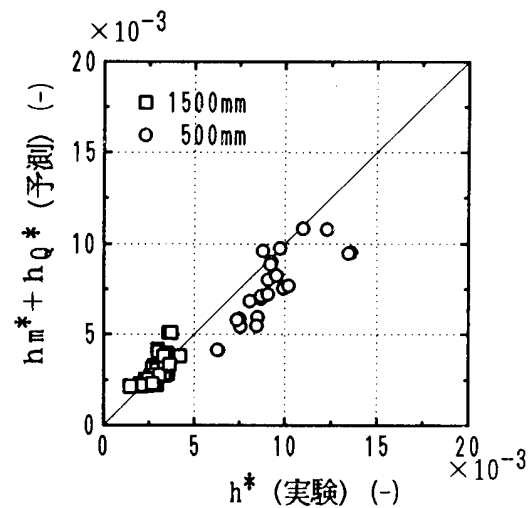

図18 無次元熱伝達率の予測值と実測值
$\mathrm{Q}^{*}>4 \times 10^{-3}$ の場合

$$
h^{*}=0.08\left(Q^{*}\right)^{2 / 3}+5.1\left(m d^{*}\right)^{4 / 3}
$$

となる。

そこでこれらの式から予測值を算出して、実測値と比較した結 果を図17及び図18に示す。

図17から、対流熱伝達率の値は比較的良く予測されていると考え られる。図18は、対流熱伝達率を無次元化した場合の比較であるが、 区画1の場合にやや差が見られる。しかし、いずれもテー夕は比較 的良くまとまっていると考えられる。

\section{6.まとめ}

区画模型を用いて、発熱速度、開口形状、区画の規模を変えて実 験を行い、区画内温度がそれほど高温とはなっていないが換気は生 じている時期の対流熱伝達について調へた。その結果、次のような 知見が得られた。

（1）無次元発熱速度を用いて対流熱伝達率の值を整理した結果、無 次元発熱速度が同じ場合、換気が生じている時期の対流熱伝達率 は、換気のない火災初期の值に比較して常に大きい。(図13、図 14)

(2)換気が生じている時期の対流熱伝達率を、火源の発熱に起因す る流れに影響される成分亡、開口を介して行なわれる換気に起因 する流れに影響される成分に分割して整理することができた。（式 (13)、式(14)、式(17)、式(18)、図15、図16)

（3）対流熱伝達率の換気に影響される成分は、無次元化した開口噴 流質量流速(式(10))をパラメー夕とすると良く整理できた。（図15、 図16）ただし、開口噴流の質量流速の無次元化に関する理論的検 討を行っていないので、今後これを行う必要がある。

(4) 2 つの成分に分割した対流熱伝達率のそれぞれの予測式を加算 して算出した対流熱伝達率の予測値と、実測值を比較した結果、 比較的よく一致した。（式(19）、式(20)、図17、図18）

なお今回の実験では開口が比較的小さく、かつ、その位置は下部 である。そのため流入空気のほとんどは火源に巻き込まれた後、ブ ルームとして上部層に貫入しており、そのため、外部から区画内に 流入する空気が直接、上部空気層内の流れに与える影響が小さくな っていることも考えられる。従って、例えば開口の位置がより上部 であれば、換気による成分が今回の実験值よりも大きくなることも 考えられる。
また、本実験は区画が立方体で、開ロが一面の壁下部に存在する 条件のみで行っているので、区画及び開口の形状が異なる場合には、 ここで提案した予測式がそのまま適用でるるあではない。形状に 対する依存は今後の検討課題である。

[謝辞]

実験に際しては東京理科大学大学院 山口純一君のご協力をいた だいたっここに記して感謝いたします。

[記号]

A : 伝熱面皘 $\left(\mathrm{m}^{2}\right)$

$\mathrm{C} p$ : 定圧比熱 $(\mathrm{kJ} / \mathrm{kg} \mathrm{K})$

$\mathrm{g}:$ 重力加速度 $\left(\mathrm{m} / \mathrm{s}^{2}\right)$

$\mathrm{H}$ : 天井高さ $(\mathbb{m})$

$\mathrm{h}$ : 対流熱伝達率 $\left(\mathrm{k} / / \mathrm{m}^{2} \mathrm{~K}\right)$

$\mathrm{hd}$ ：対流熱伝達率のうち換気に起因する流れによる成分 $\left(\mathrm{kN} / \mathrm{m}^{2} \mathrm{~K}\right)$

$h d^{*}: h m$ を無次元化した值

he：対流熱伝達率のうち火源の発熱に起因する流れによる成分 $\left(\mathrm{kN} / \mathrm{m}^{2} \mathrm{~K}\right)$

$h Q^{*}:$ hQを無次元化した値

$\mathrm{h}^{*}$ : 無次元対流熱伝達率 (式 $\left.(9)\right)$

md：区画からの流出空気の質量流速 $(\mathrm{kg} / \mathrm{s})$

$\mathrm{m \varepsilon}:$ 排気タクト内の空気の質量流速 $(\mathrm{kg} / \mathrm{s})$

$\mathrm{mi}$ : 区画への流入空気の質量流速 $(\mathrm{kg} / \mathrm{s})$

$\mathrm{mp}$ : 火源からの可然ガスの発生速度 $(\mathrm{kg} / \mathrm{s})$

$\mathrm{Q}$ : 発热速度 $(\mathrm{k}$ 要)

$Q^{*}$ ：無次元発熱速度 (式 $(8)$ )

Qc ：対流熱伝達速度 (kI)

$\mathrm{Qd}$ ：換気による失熱速度 (k)

$\mathrm{T}$ : 温度 $(\mathrm{K})$

$\mathrm{Td}$ : 開口加ら流出空気の温度 $(K)$

$\mathrm{T} \mathrm{i}$ : 開口加の流入空気の温度 $(\mathrm{K})$

$\mathrm{T} \mathrm{n}:$ 参照温度 $(\mathrm{K})($ 式 $(7))$

$T_{\infty}:$ 周辺空気の温度 $(K)$

$\Delta \mathrm{T}:$ : 画内空気と周壁表面の温度差 (K)

$\mathrm{Y}_{\mathrm{i}}$ ：化学種 Lの質量分率(添字の $\mathrm{a}$ は霧囲気空気、D は開口晬流、E排 気タクト内を表す

$\rho_{\infty} ：$ 周辺空気の密度 $\left(\mathrm{kg} / \mathrm{m}^{3}\right)$

\section{[着考文軧]}

1) 山田茂、田中㫴莪、吉野博：小規模区画における火炎初期の対流熱伝達、 日本建築学会計画系論文集 第 491 号、pp.1-8、1997.01

2) 山田茂、田中啫義、吉野博：熱伝達率と発熱速度及び区画規模との関倸 一小規模区画における火炎初期の対流熱伝達 その 2 -、日本建築学侌計画 系論文集 第 495 号、pp.1-8、1997.05

3)山口純一、山田茂、田中睹義、若松孝䚾：区画火災における開口噴流の流 量測定、日本建築学会計画系論文集 第501号、1997.11（掲載予定）

4) L.Y.Cooper, M.Harkeroad, J,Quintiere, W.Rinkinen : An Experimental Study of Upper Hot Layer Stratification in Full-Scale Multi-room Fire Scenarios, Journal of Heat Transfer, Vol. 104, pp.741-749, 1982.11

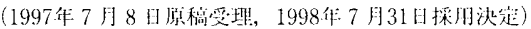

